\title{
Efficiency of Nanoparticle, Sulfate, and Zinc-Chelate Use on Biomass, Yield, and Nitrogen Assimilation in Green Beans
}

\author{
Cástor Omar Ponce-García ${ }^{1}$, Juan Manuel Soto-Parra ${ }^{1}$, Esteban Sánchez ${ }^{2, *}$, \\ Ezequiel Muñoz-Márquez ${ }^{2}$, Francisco Javier Piña-Ramírez ${ }^{1}$, María Antonia Flores-Córdova ${ }^{1}$, \\ Ramona Pérez-Leal ${ }^{1}$ and Rosa María Yáñez Muñoz ${ }^{1}$ \\ 1 Facultad de Ciencias Agrotecnológicas, Universidad Autónoma de Chihuahua. V, Carranza y Escorza S/N, \\ Col. Centro, Chihuahua 31000, Chihuahua, Mexico; omarcpg@gmail.com (C.O.P.-G.); \\ jsoto@uach.mx (J.M.S.-P.); fpinar615@hotmail.com (F.J.P.-R.); mariflor_556@hotmail.com (M.A.F.-C.); \\ rpleal@uach.mx (R.P.-L.); rosky1388@gmail.com (R.M.Y.M.) \\ 2 Centro de Investigación en Alimentación y Desarrollo A. C., Avenida Cuarta Sur No. 3820 Fraccionamiento \\ Vencedores del Desierto, Delicias 33089, Chihuahua, Mexico; emunoz@ciad.mx \\ * Correspondence: esteban@ciad.mx; Tel.: +52-639-474-8704
}

Received: 16 January 2019; Accepted: 1 March 2019; Published: 8 March 2019

\begin{abstract}
The introduction of nanofertilizers (Nfs) in agriculture has allowed the development of new technologies that enhance the productivity of crops. Within the most studied Nfs we find metal oxides, especially $\mathrm{ZnO}$; however, the results of various experiments provide contradictory data on the growth variables. Therefore, this study intended to evaluate the efficiency associated with the use of nanoparticles, sulfates, and zinc-chelates in Phaseolus vulgaris L. cv. Strike grown in acid soil, as well as to evaluate its production, total biomass, and nitrogen assimilation. Phaseolus vulgaris L. cv. Strike plants were sprouted and grown in polyethylene bags containing $3 \mathrm{~kg}$ of acid soil ( $\mathrm{pH}$ 6.8) in an experimental greenhouse and were watered with a nutritious solution. A completely randomized design including ten treatments and five repetitions was used. Treatments consisted of applying different zinc sources (sulfate, DTPA chelate, and zinc oxide nanoparticles) to four different doses $(0,25,50$, and $100 \mathrm{ppm}$ of zinc). Results obtained indicated that the doses best favoring an increase in biomass, production, and nitrogen assimilation were $50 \mathrm{ppm}$ of $\mathrm{ZnSO}_{4}, 100 \mathrm{ppm}$ of DTPA-Zn, and $25 \mathrm{ppm}$ of zinc oxide nanofertilizers ( $\mathrm{NfsOZn}$ ). Hence, the dose containing $25 \mathrm{ppm}$ of $\mathrm{NfsOZn}$ was the most efficient dose, since at a lower dose it was able to equalize biomass accumulation, production, and nitrogen assimilation as compared to $\mathrm{ZnSO}_{4}$ and DTPA- $\mathrm{Zn}$ sources. However, further research is required, given that high-concentration doses were toxic for beans. Finally, it is worth highlighting that zinc oxide nanoparticles have a huge potential to be used as nanofertilizers if applied in optimal concentrations.
\end{abstract}

Keywords: Phaseolus vulgaris L.; nanofertilizers; efficiency; fertilization; micronutrients

\section{Introduction}

Nanotechnology is an emerging science aimed at understanding and creating materials, devices, and systems to exploit the nanoscale properties of various materials [1]. This area of research in modern materials science is able to provide innovative and varied technological applications ranging from sophisticated medicinal techniques to food processing and agricultural production [2]. Nanomaterials currently provide physical and chemical properties that can be useful in various areas [3]. In farming, nanotechnology has developed different products to help improve soil fertilization, reduce the occurrence of diseases, and increase crop quality and production [4]. 
The materials with diameters that range from 1 to $100 \mathrm{~nm}$ and which can provide one or more nutrients to plants are known as nanofertilizers (Nfs). In comparison with conventional fertilizers, $\mathrm{Nfs}$ are expected to improve crop growth and productivity, as well as to reduce losses and minimize environmental impact [5].

Studies done using zinc oxide nanofertilizers ( $\mathrm{NfsOZn}$ ) have shown an increase in production, biomass, root, germination, and chlorophyll concentration [4]; however, their excessive use can produce stress in plants, affecting protein, carbohydrate, and DNA synthesis [6]. Thus, it is of paramount importance to conduct studies comparing the positive effects of Nfs vs. conventional fertilizers [5].

Zinc is considered to be one of the eight essential micronutrients for plants. It is necessary in small amounts and is crucial for appropriate development [7], since it promotes an increase in biomass and enzymatic action. Moreover, it stabilizes chlorophyll molecules and regulates gene expression [8,9].

The common bean (Phaseolus vulgaris L.) is one of the most important grain legumes for human consumption around the world [10]. The green bean (fresh pod bean) has a high nutritional value due to its high mineral, fiber, protein, carbohydrate, and vitamin content [11]; however, this plant is highly prone to showing zinc deficiency. The Strike green bean is a variety that in several studies has shown a lower yield and quality compared to other cultivars [11,12]; $\mathrm{NpsOZn}$ are an alternative to increases the quality and production of this variety.

Therefore, this study intended to evaluate the efficiency associated with the use of nanoparticles, sulfates, and zinc-chelates in Phaseolus vulgaris L. cv. Strike grown in acid soil, as well as to evaluate its production, total biomass, and nitrogen assimilation.

\section{Materials and Methods}

\subsection{Crop Management}

Phaseolus vulgaris L. cv. Strike bean plants were sprouted and grown in polyethylene bags containing $3 \mathrm{~kg}$ of soil (sandy loam, pH 6.8, electrical conductivity $0.51 \mathrm{dS} \mathrm{m}^{-1}$, organic matter $1.5 \%$, water saturation $48 \%, 0.22 \mathrm{ppm} \mathrm{Zn,} 0.4 \mathrm{ppm} \mathrm{Cu}, 5.4 \mathrm{ppm} \mathrm{Fe}$, and $1.3 \mathrm{ppm} \mathrm{Mn)} \mathrm{in} \mathrm{an} \mathrm{experimental}$ greenhouse located in Chihuahua City, Mexico, at a mean temperature of $30 \pm 5^{\circ} \mathrm{C}$.

A nutritious solution containing $6 \mathrm{mM}$ of $\mathrm{NH}_{4} \mathrm{NO}_{3}, 1.6 \mathrm{mM}$ of $\mathrm{K}_{2} \mathrm{HPO}_{4}, 2.4 \mathrm{mM}$ of $\mathrm{K}_{2} \mathrm{SO}_{4}$, $4.0 \mathrm{mM}$ of $\mathrm{CaCl}_{2} \bullet 2 \mathrm{H}_{2} \mathrm{O}, 1.4 \mathrm{mM}$ of $\mathrm{MgSO}_{4}, 2 \mu \mathrm{M}$ of $\mathrm{MnSO}_{4} \bullet \mathrm{H}_{2} \mathrm{O}, 1.0 \mu \mathrm{M}$ of $\mathrm{ZnSO}_{4} \bullet 7 \mathrm{H}_{2} \mathrm{O}, 0.25 \mu \mathrm{M}$ of $\mathrm{CuSO}_{4} \bullet 5 \mathrm{H}_{2} \mathrm{O}, 0.3 \mu \mathrm{M}$ of $\left(\mathrm{NH}_{4}\right)_{6} \mathrm{Mo}_{7} \mathrm{O}_{24} \bullet 4 \mathrm{H}_{2} \mathrm{O}$, and $0.5 \mu \mathrm{M}$ of $\mathrm{H}_{3} \mathrm{BO}_{3}$ prepared with distilled water was applied [13]. The $\mathrm{pH}$ of the solution ranged from 5.5 to 6.0. The solution was applied until field capacity ( $24 \mathrm{~mL}$ per $100 \mathrm{~g}$ of soil) every third day. The treatment application began 15 days after germination and was done using $200 \mathrm{~mL}$ of the zinc solution for each plant (once per week).

\subsection{Experimental Design and Treatments}

A completely randomized design including ten treatments and five repetitions was used. In Table 1, the sources and doses applied for each treatment are shown.

Table 1. Description of treatments (dosage and form of application).

\begin{tabular}{|c|c|c|}
\hline Treatments & Doses $\left(\mathrm{mg} \mathrm{kg}^{-1}\right)$ & Source of $\mathrm{Zn}$ \\
\hline Control & 0 & \\
\hline $\mathrm{S} 25$ & 25 & \\
\hline S50 & 50 & Sulfate \\
\hline S100 & 100 & \\
\hline Q25 & 25 & \\
\hline Q50 & 50 & DTPA chelate \\
\hline Q100 & 100 & \\
\hline N25 & 25 & \\
\hline N50 & 50 & Oxide \\
\hline N100 & 100 & \\
\hline
\end{tabular}




\subsection{Nanofertilizer Characterization}

The material applied as Nfs was zinc oxide obtained by wet chemistry methodology in the form of wurtzite crystals with an average size of $50 \mathrm{~nm}$ with no contaminants, a purity level of $99.7 \%$ (Figure 1), and a density of $5.61 \mathrm{~g} \mathrm{~cm}^{-3}$. Figure 2 shows the morphology of the sample by scanning and transmission electron microscopy. The material was provided by the company "Investigación y Desarrollo de Nanomateriales S.A. de C.V.".

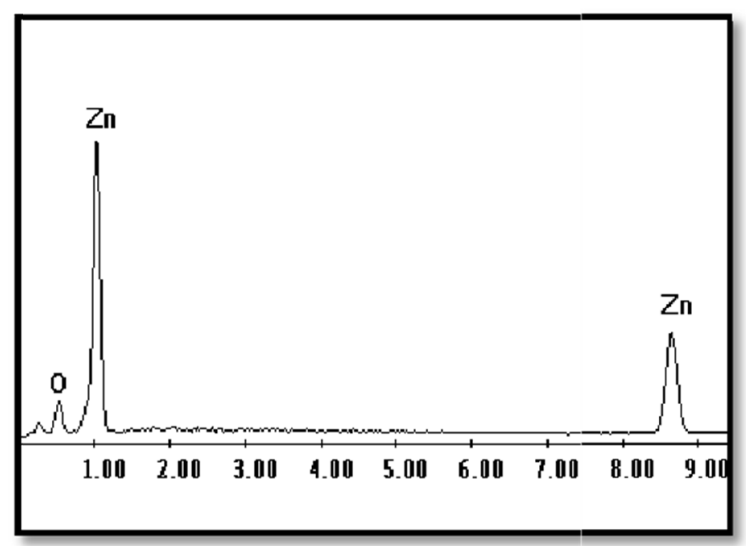

Figure 1. Elemental analysis (chemical composition) of zinc oxide nanofertilizers ( $\mathrm{NfsOZn}$ ) by energy dispersive X-ray (EDX).

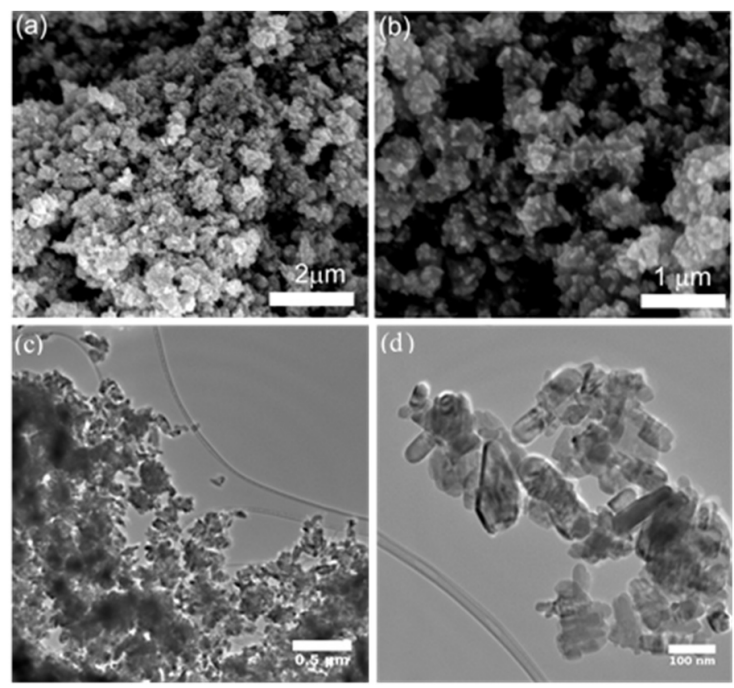

Figure 2. (a,b) NfsOZn morphology using electron microscopy scans. (c,d) NfsOZn morphology using electron microscopy transmission.

\subsection{Plant Sampling}

Sixty days after germination (dag), full plants were sampled. The plants were at the phenological phase of full development and maturity of the fruit. The fresh material was used to quantify biomass, yield, and photosynthetic pigments, while the dry material was used to determine zinc content. Four repetitions per treatment were used for each variable analyzed.

\subsection{Plant Analysis}

\subsubsection{Biomass}

Leaf biomass production was obtained from the average weight per plant based on dry material (g). 


\subsubsection{Yield}

Plant yield was expressed as the mean fruit fresh weight per plant. Green beans collected from each plant were weighed at sampling. Commercial yield represents fruits of acceptable standards, while fruits lacking these qualities are represented by non-commercial or residual yield. Total yield (g per plant) is the sum of both types of yield.

\subsubsection{Assay and Determination of the In Vivo Enzymatic Activity of Nitrate Reductase}

The in vivo Nitrate Reductase (NR) activity (EC 1.6.6.1) was determined by the assay [14]. Leaf blades were cut into $5 \mathrm{~mm}$ sections $(100 \mathrm{mg})$ and placed in $10 \mathrm{~cm}^{3}$ of incubation buffer $(100 \mathrm{mM}$ K-phosphate buffer, $\mathrm{pH} 7.5$, and $1 \%(v / v)$ propanol). The samples were infiltrated and the intracellular spaces of the tissues were flushed with buffer using a vacuum ( $0.08 \mathrm{MPa})$. After $5 \mathrm{~min}$, the vacuum was released and the samples were re-evacuated, incubated at $30{ }^{\circ} \mathrm{C}$ in darkness for $1 \mathrm{~h}$, and finally placed in a boiling water bath to stop the NR activity. The resulting nitrite concentration was determined by spectrophotometry at $540 \mathrm{~nm}$ in a reaction mixture containing $2 \mathrm{~cm}^{3}$ of extract, $2 \mathrm{~cm}^{3}$ of $1 \%(\mathrm{~m} / \mathrm{v})$ sulfanilamide in $1.5 \mathrm{M} \mathrm{HCl}$, and $2 \mathrm{~cm}^{3} 0.02 \%(\mathrm{~m} / \mathrm{v}) \mathrm{N}$-(1-naphthyl)-ethylenediamine dihydrochloride in $0.2 \mathrm{M} \mathrm{HCl}\left(\mathrm{NR}+\mathrm{NO}_{3}{ }^{-}\right)$, following the same method but using a modified incubation buffer containing $50 \mathrm{mM} \mathrm{KNO}{ }_{3}$. The $\mathrm{NR}$ induced by $\mathrm{NO}_{3}{ }^{-}$and $\mathrm{Mo}\left(\mathrm{NR}+\mathrm{NO}_{3}{ }^{-}+\mathrm{MO}\right)$, and the $\mathrm{NR}$ induced by $\mathrm{NO}_{3}{ }^{-}$and $\mathrm{Mo}\left(\mathrm{NR}+\mathrm{NO}_{3}{ }^{-}+\mathrm{Mo}\right.$ ), were also determined using a modification of the incubation buffer containing $20 \mathrm{mM} \mathrm{NaMoO}_{4}$ and $50 \mathrm{mM} \mathrm{KNO}_{3}$ plus $20 \mathrm{mM} \mathrm{NaMoO}_{4}$, respectively. The resulting nitrate concentration was also determined by spectrophotometry.

\subsubsection{Photosynthetic Pigments}

The method used for leaf pigment extraction and quantification was the method described by Wellburn, 1994 [15], which required weighing $0.2-0.3 \mathrm{~g}$ of fresh photosynthetic plant material (leaves) in $7 \mathrm{~mm}$ diameter foliar disks. Ten milliliters of pure methanol $\left(\mathrm{CH}_{3} \mathrm{OH}\right)$ was added. Samples were then incubated at room temperature in darkness for $24 \mathrm{~h}$. After this period elapsed, absorbance was measured at $470 \mathrm{~nm}$ (carotenoids), $653 \mathrm{~nm}$ (chlorophyll b, chl b), and $666 \mathrm{~nm}$ (chlorophyll a, chl a). The pigment concentration calculation was carried out according to the formulas below [15].

$$
\begin{array}{cc}
\text { Chl a : }\left[15.65\left(\mathrm{~A}_{666}\right)-\left(7.34\left(\mathrm{~A}_{653}\right)\right)\right] & \frac{(\mathrm{Chl} \mathrm{a})\left(V_{1}\right)\left(p_{1}\right)}{\left(p_{2}\right)\left(2 \pi \mathrm{r}^{2}\right)(n)} \\
\text { Chl b : [27.05 } \left.\left(\mathrm{A}_{653}\right)-\left(11.21\left(\mathrm{~A}_{666}\right)\right)\right] & \\
\frac{(\mathrm{Chl} \mathrm{b})\left(V_{1}\right)\left(p_{1}\right)}{\left(p_{2}\right)\left(2 \pi \mathrm{r}^{2}\right)(n)}
\end{array}
$$

where $V_{1}$ is the extraction volume, $p_{1}$ is the weight in g per foliar disk ( $7 \mathrm{~mm}$ in diameter), $p_{2}$ is the total weight in $\mathrm{g}, n$ is the number of foliar disks ( $7 \mathrm{~mm}$ in diameter), and $r^{2}$ is the radius of the foliar disks. The sum of chlorophyll a and chlorophyll b concentrations resulted in total chlorophyll, which was expressed in $\mu \mathrm{g} \mathrm{cm}^{-2}$.

\subsubsection{Nitrogen Determination}

A subsample of $0.1 \mathrm{~g}$ dry weight was digested with sulphuric acid and $\mathrm{H}_{2} \mathrm{O}_{2}$, according to Wolf [16]. After dilution with deionized water, a $1 \mathrm{~mL}$ aliquot of the digest was added to the reaction medium ( $5 \%$ potassium sodium tartrate, $100 \mu \mathrm{M}$ sodium phosphate, and $5.4 \%(w / v)$ sodium hydroxide) with $15 / 0.03 \%(w / v)$ sodium salicylate/sodium nitroprusside and $5.35 \%(v / v)$ sodium hypochlorite. The samples were incubated at $37^{\circ} \mathrm{C}$ for $45 \mathrm{~min}$ and organic $\mathrm{N}$ was measured by spectrophotometry at A 630 as performed by Baethgen and Alley [17]. The results were expressed as a percentage. 


\subsubsection{Zinc Content Determination}

The $\mathrm{Zn}$ concentration was determined by an Inductive Coupled Plasma Optical Emission Spectrometer (Agilent Technologies 700 Series ICP-OES, CA, USA), according to the method described by Karacan and Aslantas [18]. The Zn concentration was expressed in $\mathrm{mg} \mathrm{kg}^{-1}$ of dry weight.

\subsection{Statistical Analysis}

All data were subject to analysis. The LSD test $(95 \%)$ was used to determine the difference between the means of treatment [19]. The significance levels of both tests are expressed as follows: ${ }^{*} p<0.05$, ${ }^{* *} p<0.01,{ }^{* * *} p<0.001$, and NS (not significant).

\section{Results and Discussion}

\subsection{Biomass and Production}

The studies done using zinc application showed an increase in the productivity of various crops [20]. This experiment found that the best doses for each fertilizer applied were as follows: $50 \mathrm{mg}$ $\mathrm{kg}^{-1}$ for $\mathrm{ZnSO}_{4}, 100 \mathrm{mg} \mathrm{kg}^{-1}$ for DTPA-Zn, and $25 \mathrm{mg} \mathrm{kg}^{-1}$ for NfsOZn, which increased production by $13.7,20.4$, and $15.5 \mathrm{~g}$ per plant, respectively, compared to the control reference, to which no fertilizer was applied (Figure 3). These data concur with those reported by Pérez-Álvarez et al. [21] and Weldua et al. [22], who identified an increase in production after applying zinc. In $\mathrm{NfsOZn}$, low doses were observed to work better than high doses, which may be due to the fact that Nfs are smaller than $100 \mathrm{~nm}$, which facilitates penetration in plants [23]. However, it is worth noting that high $\mathrm{NfsOZn}$ doses (400 $\mathrm{mg} \mathrm{kg}^{-1}$ ) may affect root development in plants [24].

Zinc deficiency in plants affects photosynthesis due to altered chloroplast pigments [25]. The most visible zinc deficiency symptoms are short internodes, a decrease in leaf size, and delayed maturity [26].

Mankad et al. [27] mentioned that growth enhancement by ZnO NPs may be attributed to the release of $\mathrm{Zn}^{2+}$ ions for greater plant growth. The same authors concluded that nanoparticles, if applied at optimum concentration, can enhance the growth of plants both morphophysiologically as well as biochemically.

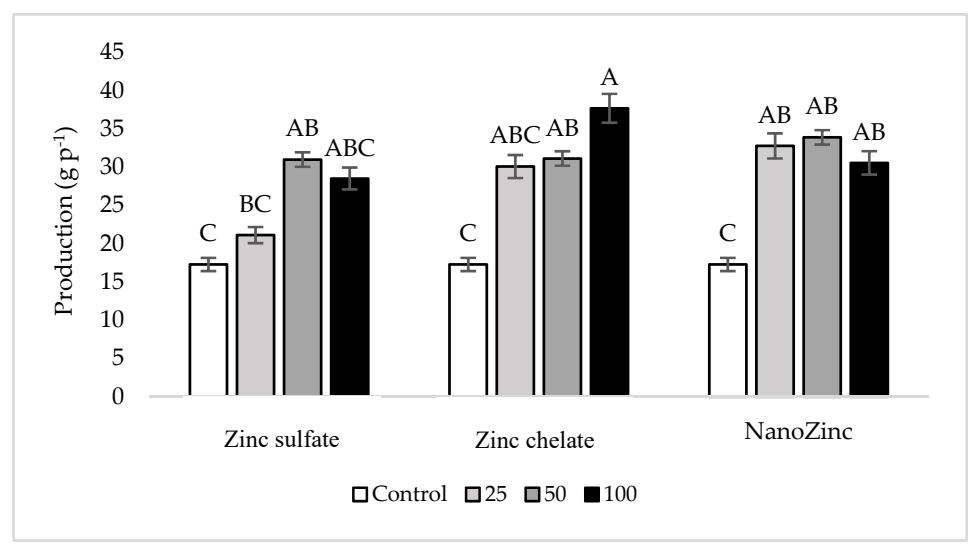

Figure 3. Effect of applying nanofertilizers, chelates, and zinc sulfates in green bean production per plant. Letters show significant differences.

A number of studies have shown that biomass accumulation is a basic parameter by which fertilization efficiency in crops can be evaluated [28]. This study found significant differences in biomass accumulation due to the effects caused by applying different sources of zinc. The doses that showed greater biomass accumulation were $25 \mathrm{ppm}$ of $\mathrm{NPsOZn}, 50 \mathrm{mg} \mathrm{kg}^{-1}$ of $\mathrm{ZnSO}_{4}$, and $100 \mathrm{ppm}$ of Zn-DTPA at $42 \%, 35 \%$, and $45 \%$ increments, respectively, compared to the control with no fertilizer application (Figure 4). These data align with those reported by Sida-Arreola et al. [29] 
and Pérez-Álvarez et al. [21], who identified that zinc application in the form of chelates and sulfates increased the biomass of common beans. A number of studies done with various crops showed that $\mathrm{NfsOZn}$ application increases plant growth and development [30].

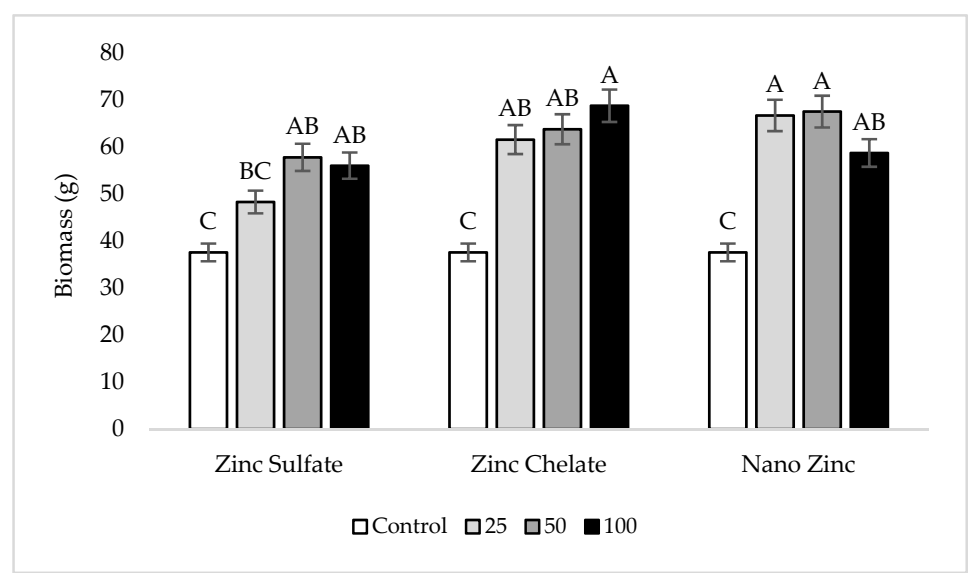

Figure 4. Effect of applying nanofertilizers, chelates, and zinc sulfates to the total biomass of green beans cv. Strike. Letters show significant differences.

\subsection{In Vivo Nitrate Reductase Activity}

NR is the first enzyme participating in nitrogen assimilation and its activity is regulated by different environmental stimuli, such as nitrate and molybdenum content and the ratio between sugar and amino acid content [31,32].

Treatments with zinc application were observed to induce increased NR enzyme activity as compared to the control treatment (Figure 5). The best doses were $25 \mathrm{mg} \mathrm{kg}^{-1}$ of NfsOZn, $50 \mathrm{mg} \mathrm{kg}^{-1}$ of $\mathrm{ZnSO}_{4}$, and $100 \mathrm{mg} \mathrm{kg}^{-1}$ of $\mathrm{Zn}$-DTPA. These results are consistent with the data obtained for the biomass and production variables.

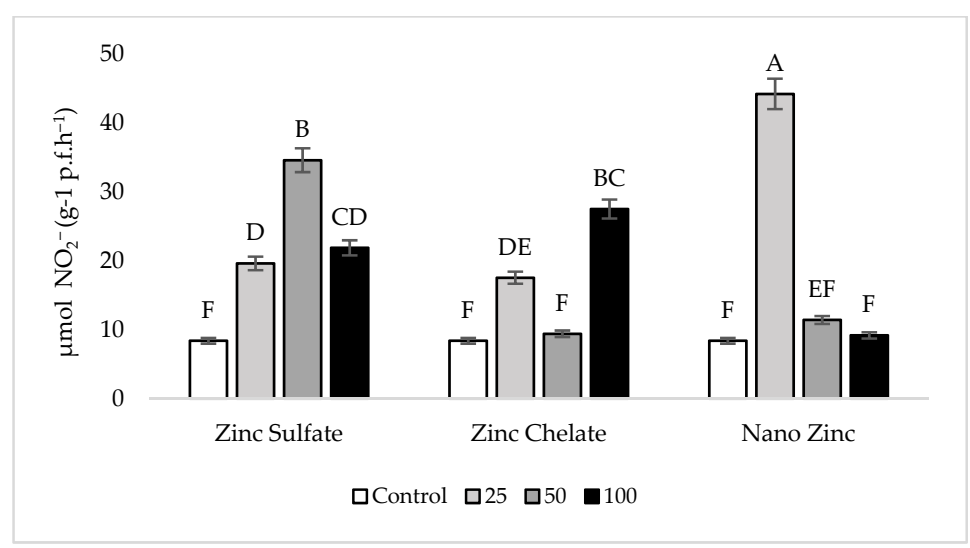

Figure 5. Endogenous nitrate reductase activity induced by nitrates due to the effect of applying nanofertilizers, chelates, and zinc sulfates in green beans cv. Strike. Letters show significant differences.

Zinc is considered to be one of the eight essential micronutrients for plants. It is necessary in small amounts and crucial for appropriate development [7], since it promotes an increase in biomass and enzymatic action. Moreover, it stabilizes chlorophyll molecules and regulates gene expression $[8,9]$. Additionally, it has been observed that zinc is required for various types of enzyme activity, carbohydrate metabolism, and protein synthesis [33]. Zinc is an essential micronutrient for biological systems and plays a crucial physiological role in protein synthesis and metabolism. It is also a structural constituent and regulatory cofactor in enzymes and proteins involved in many biochemical pathways. Almost $40 \%$ of the Zn-binding proteins are transcription factors needed for 
gene regulation, and $60 \%$ are enzymes and proteins involved in ion transport. Zinc plays an important role in increasing leaf iron concentration and also is an integral part of many enzymes and proteins [34]. Regarding the latter, an important relationship was found between the nutritional status of zinc and $\mathrm{N}$ assimilation, showing an important concentration of $\mathrm{Zn}$ ions, which favors the in vivo enzymatic activity of nitrate reductase. However, as occurred with regard to the effect obtained in biomass accumulation and production, the efficiency of the zinc application will depend on the source and doses of the application.

\subsection{Content of Photosynthetic Pigments}

Chlorophyll a, is the photosynthetic pigment of greater amount found in plants. It is more sensitive to degradation and is a good indicator that can be used to detect stress conditions in plants, such as those produced by applying excess metal nanoparticles $[35,36]$. This study found that chlorophyll content in bean leaves was similar for the treatments applying $25 \mathrm{ppm} \mathrm{NfsOZn}$, and 25, 50, and $100 \mathrm{ppm}$ DTPA-Zn, showing an increase of $83.14,80.28,80.5$, and $77.04 \%$, respectively, with respect to the control (Figure 6). It was observed that as the dose of $\mathrm{NfsOZn}$ increased, the pigment concentration was lower. This result concurs with that reported by Du et al. [35], who mentioned that the application of high doses to the soil may cause toxicity.

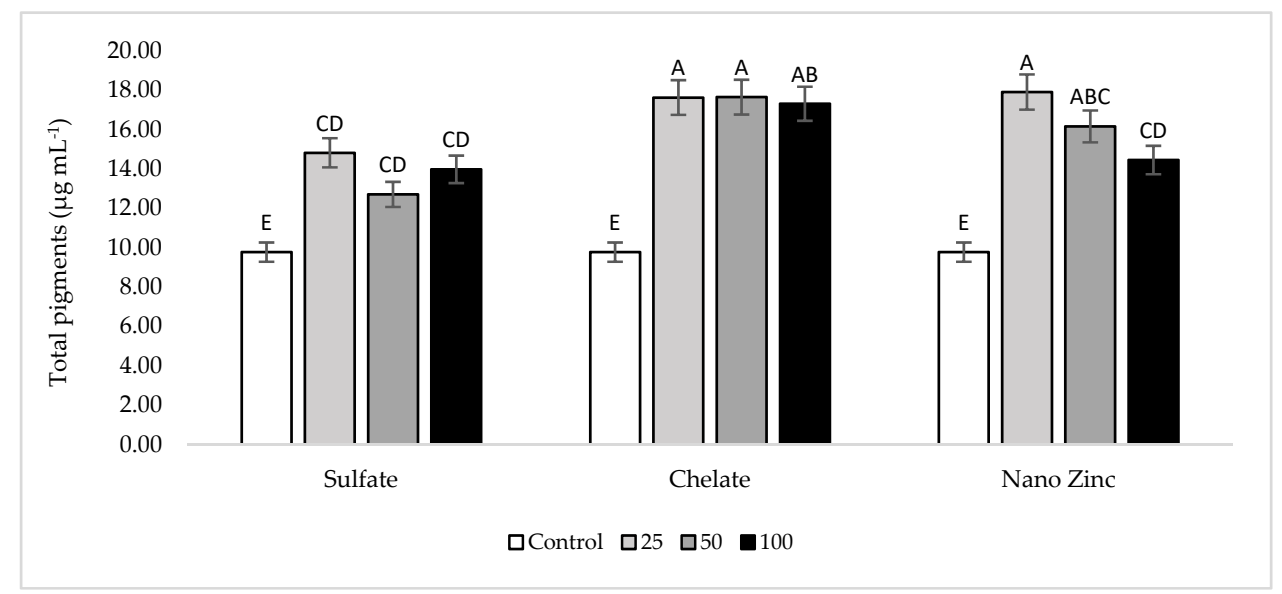

Figure 6. Total pigment concentration in leaf of bean cv. Strike as a result of applying nanofertilizers, chelates, and zinc sulfates. Letters shoe significant differences.

Samreen et al. [36], while evaluating the effect of zinc application on rate of growth as well as on chlorophyll and protein, concluded that applying $2 \mu \mathrm{M}$ to the nutritious solution improved the plant growth of Vigna radiate, chlorophyll content, raw protein, and zinc content.

\subsection{Zinc Content}

Zinc is absorbed in very small amounts by plants in the form of a divalent cation $\left(\mathrm{Zn}^{+2}\right)$, and zinc availability is greater when the $\mathrm{pH}$ is lower. Zinc concentrations lower than $20 \mathrm{mg} \mathrm{kg}^{-1}$ in dry matter can cause severe deficiencies in crops [37]; however, crops can have different tolerance ranges. Certain species like soybean, rice, and beans are most sensitive to zinc deficiency [38].

In this experiment, it was observed that $\mathrm{ZnSO}_{4}$ application increased zinc concentration in green beans. The $100 \mathrm{mg} \mathrm{kg}^{-1}$ application yielded better results in the root, leaf, and fruit, having shown an increase of 31, 44.5, and $5 \mathrm{mg} \mathrm{kg}^{-1}$, respectively (Figure 7).

When applying DTPA-Zn, the $25 \mathrm{mg} \mathrm{kg}^{-1}$ dose was observed to accumulate a greater concentration in the leaf and root, while the $100 \mathrm{mg} \mathrm{kg}^{-1}$ dose did so in the fruit and stalk (Figure 7). Concentrations in tissues were found in the following order: stalk, root, leaf, and fruit. 

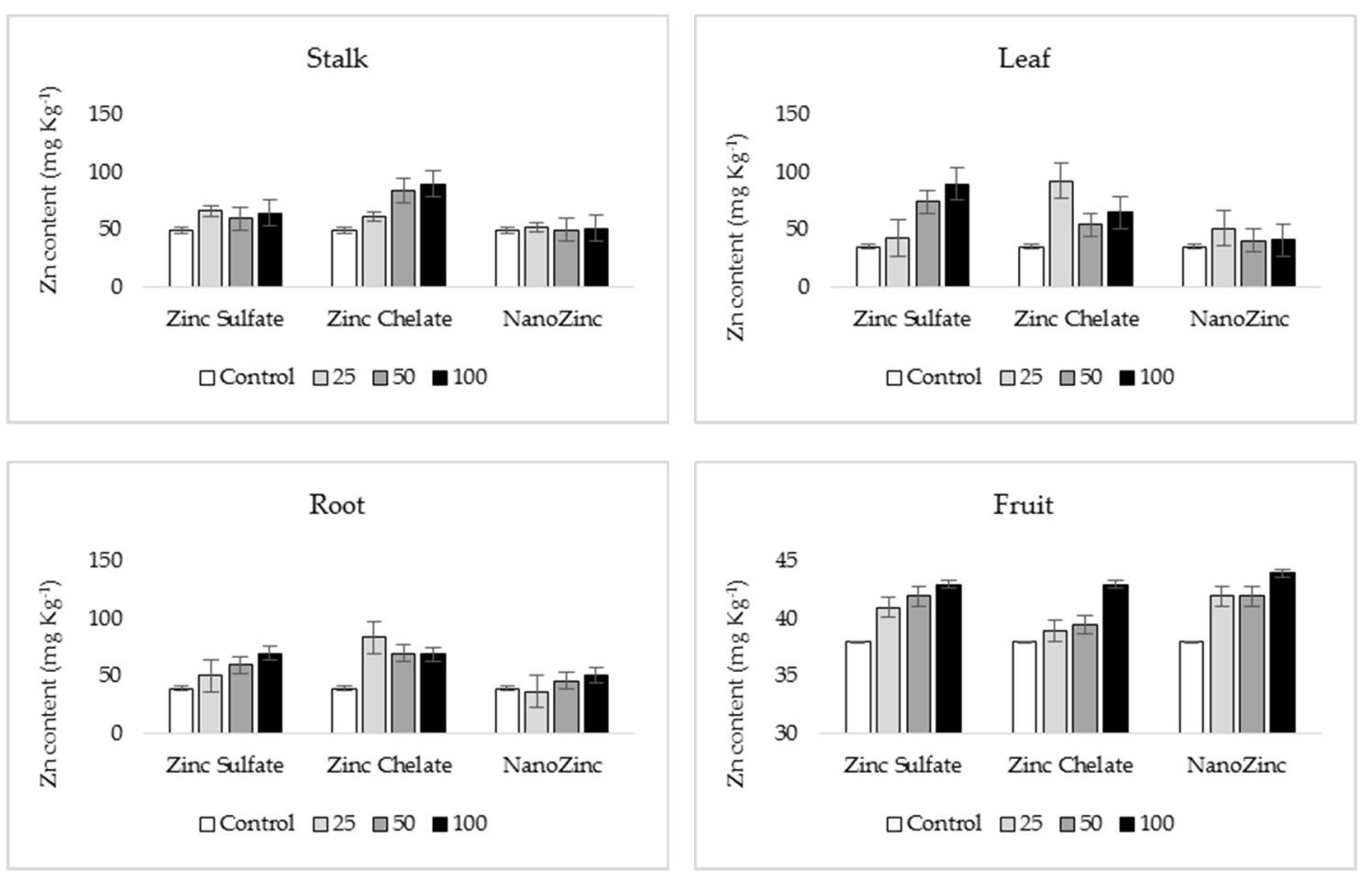

Figure 7. Zinc concentration in the root, stalk, leaf, and fruit of green beans cv. Strike in response to the application of nanofertilizers, chelates, and zinc sulfates.

$\mathrm{NfsOZn}$ showed an increase in zinc concentration compared to the control treatment applied to the root, leaf, and fruit; however, the results seen in the stalk were similar to those shown by the control treatment (Figure 7). The NfsOZn treatment was observed to show the highest zinc concentration in the fruit, which suggests that $\mathrm{NfsOZn}$ can help in the biofortification of $\mathrm{cv}$. Strike green beans.

In general, there is limited information on the effect that $\mathrm{NfsOZn}$ have on the physiological and biochemical parameters of beans. Therefore, it is necessary to conduct a more in-depth evaluation of the effect caused by nanoparticles (nanofertilizers) on the physiology and biochemistry of various farm crops, as well as the impact thereof on the environment. Moreover, a negative effect has been observed for high zinc doses over the parameters studied, such as biomass accumulation, yield, photosynthetic pigment content, and the in vivo activity of nitrate reductase. Hence, it is recommendable to study this. In this regard, Wang et al. [39] mentioned that zinc is a necessary element for plants, but excess Zn can be detrimental. The same authors stated that excess $\mathrm{Zn}$ exerts its toxicity partially through disturbing the nutrient balance and inducing oxidative stress in plants. These data will be helpful for better understanding of toxicity of $\mathrm{Zn}$ and the adaptive mechanism in $\mathrm{Zn}$ non-hyperaccumulator plants.

\section{Conclusions}

The best doses favoring an increase in biomass, production, and nitrogen assimilation were $50 \mathrm{ppm}$ of $\mathrm{ZnSO}_{4}, 100 \mathrm{ppm}$ of DTPA-Zn, and $25 \mathrm{ppm}$ of NfsOZn. Hence, the dose containing $25 \mathrm{ppm}$ of $\mathrm{NfsOZn}$ was the most efficient dose, since at a lower dose it was better able to equalize biomass accumulation, production, and nitrogen assimilation as compared to $\mathrm{ZnSO}_{4}$ and DTPA-Zn sources. The efficiency of the zinc application depended on the source and doses of the application. Further research is required, given that high NfsOZn doses were toxic for beans. Finally, it is worth highlighting that zinc oxide nanoparticles have a huge potential to be used as nanofertilizers if applied in optimal concentrations. 
Author Contributions: E.S. and C.O.P.-G. designed the study. J.M.S.-P. and R.P.-L. analyzed the data. E.S. and C.O.P.-G. prepared the manuscript, while E.M.-M., F.J.P.-R., R.P.-L. and R.M.Y.M. conducted the experiments. C.O.P.-G., J.M.S.-P. and E.S. organized the data and performed the statistical analysis. All authors read and approved the final manuscript.

Funding: This research work was funded by the Consejo Nacional de Ciencia y Tecnología (CONACyT-National Science and Technology Council of Mexico), and was duly approved in the Convocatoria Atención a Problemas Nacionales: Project \#1529 "Biofortification of basic agricultural crops representing the key to combatting malnutrition and ensuring food security in Mexico".

Acknowledgments: We would like to thank the Consejo Nacional de Ciencia y Tecnología (CONACyT-Mexico) for the support provided by means of the Convocatoria Atención a Problemas Nacionales: Project \#1529 "Biofortification of basic agricultural crops representing the key to combat malnutrition and ensure food security in Mexico." In addition, we thank the company "Investigación y Desarrollo de Nanomateriales S.A de C.V." for the donation of zinc oxide nanoparticles ( $\mathrm{ZnO}-50 \mathrm{~nm})$.

Conflicts of Interest: The authors declare no conflict of interest.

\section{References}

1. Solanki, P.; Bhargava, A.; Chhipa, H.; Jain, N.; Panwar, J. Nano-fertilizers and their Smart delivery system. In Nanotechnologies in Food and Agriculture; Rai, M., Ribeiro, C., Mattoso, L., Duran, N., Eds.; Springer: Campinas, Brazil, 2015; pp. 81-90.

2. Sirelkhatim, A.; Mahmud, S.; Seeni, A.; Mohamad, N.H.; Ling, A.; Mohd, S.K.; Hasan, H.; Mohamad, D. Review on Zinc Oxide Nanoparticles: Antibacterial Activity and Toxicity Mechanism. Nano-Micro Lett. 2015, 7, 219-242. [CrossRef] [PubMed]

3. Ledezma-Delgadillo, A.; Sánchez-Chávez, E. Nanofertilizantes. In Nutrición Mineral de las Plantas; Sánchez-Chávez, E., Preciado-Rangel, P., Romero-Monreal, L., Soto-Parra, J.M., Sida-Arreola, J.P., Eds.; Avances en la nutrición de cultivos; NUVE: Granada, España, 2016.

4. Servin, A.; Elmer, W.; Mukherjee, A.; De la Torre-Roche, R.; Hamdi, H.; White, J.C.; Dimkpa, C. A review of the use of engineered nanomaterials to suppress plant disease and enhance crop yield. J. Nanopart. Res. 2015, 17, 92. [CrossRef]

5. Liu, R.; Lal, R. Potentials of engineered nanoparticles as fertilizers for increasing agronomic productions. Sci. Total Environ. 2015, 514, 131-139. [CrossRef] [PubMed]

6. Rico, C.M.; Peralta-Videla, J.R.; Gardea-Torresdey, J.L. Chemestry, biochemistry of nanoparticles and their role in antioxidant defense system in plants. In Nanotechnology and Plant Sciences; Siddiqui, M.H., Al-Whaibi, M.H., Mohammadm, F., Eds.; Springer: New York, NY, USA, 2015; pp. 1-18.

7. Méndez-Argüello, B.; Vera-Reyes, I.; Mendoza-Mendoza, E.; García-Cerda, L.A.; Puente-Urbina, B.A.; Lira-Saldívar, R.H. Promoción del crecimiento en plantas de Capsicum annuum por nanopartículas de óxido de zinc. Nova Sci. 2016, 8, 140-156. [CrossRef]

8. Burman, U.; Saini, M.; Kumar, P. Effect of zinc oxide nanoparticles on growth and antioxidant system of chickpea seedlings. Toxicol. Environ. Chem. 2013, 95, 605-612. [CrossRef]

9. Bonilla, I. Introducción mineral de las plantas. Los elementos minerals. In Fundamentos de Fisiología Vegetal; Azcón-Bieto, J., Talón, M., Eds.; McGraw-Hill Interamericana: Madrid, España, 2013; pp. 103-122.

10. Espinoza-García, N.; Martínez-Martínez, R.; Chávez-Servia, J.L.; Vera-Guzmán, A.M.; Carrillo-Rodríguez, J.C.; Heredia-García, E.; Velasco-Velasco, V.A. Contenido de minerales en semilla de poblaciones nativas de frijol común (Phaseolus vulgaris L.). Rev. Fitotec. Mex. 2016, 39, 215-223.

11. Salinas Ramírez, N.; Escalante Estrada, J.A.; Rodríguez González, M.; Sosa Montes, E. Rendimiento y calidad nutrimental de frijol ejotero en dos ambientes. Rev. Fitotec. Mex. 2012, 35, 317-323.

12. Castillo, F.S.D.; Durán Paredes, M.; Pérez, M.; del Carmen, E.; Magdaleno Villar, J.J. Variedades y densidades de población de frijol ejotero cultivado bajo invernadero e hidroponía. Revista Mexicana de Ciencias Agrícolas 2017, 8, 1187-1193. [CrossRef]

13. Sanchez, E.; Rivero, R.M.; Ruiz, J.M.; Romero, L. Changes in biomas, enzymatic activity and protein concentration in roots and leaves of green bean plants (Phaseolus vulgaris L.) cv. Strike under high $\mathrm{NH}_{4} \mathrm{NO}_{3}$ applications rates. Sci. Hortic. 2004, 99, 237-248. [CrossRef]

14. Jaworski, E.G. Nitrate reductase assay in intact plant tissues. Biochem. Biophys. Res. Commun. 1971, 43, 1274-1279. [CrossRef] 
15. Wellburn, A.R. The spectral determination of chlorophylls a and $b$, as well as total carotenoids, using various solvents with spectrophotometers of different resolution. J. Plant Physiol. 1994, 144, 307-313. [CrossRef]

16. Wolf, B.A. Comprehensive system of leaf analysis and its use for diagnosing crop nutrient status. Commun. Soil Sci. Planta Anal. 1982, 13, 1035-1059. [CrossRef]

17. Baethgen, W.E.; Alley, M.M. A manual colorimetric procedure for measuring ammonium nitrogen in soil and plant. Commun. Soil Sci. Plant Anal. 1989, 20, 961-969. [CrossRef]

18. Karacan, S.; Aslantas, N. Simultaneous preconcentration and removal of iron, chromium, nickel with $\mathrm{N}, \mathrm{N}$-etylenebis-(ethane sulfonamide) ligand on activated carbon in aqueous solution and determination by ICP-OES Mehmet. J. Hazard. Mater. 2008, 155, 551-557. [CrossRef] [PubMed]

19. Statistical Analysis System. SAS/STAT Users Guide: Statics, Ver. 9.00; SAS Institute, Inc.: Cary, NC, USA, 2007; 1503p.

20. Dimkpa, C.O.; Bindraban, P.S. Fortification of micronutrients for efficient agronomic production: A review. Agron. Sustain. Dev. 2016, 36, 7. [CrossRef]

21. Pérez-Álvarez, S.; Sida-Arrerola, J.P.; Sánchez, E.; Ardisana, E.F.H. Expression analysis and biochemical characterization of beans plants biofortificated with zinc. Saudi J. Biol. Sci. 2017, 24, 1322-1326. [CrossRef] [PubMed]

22. Weldua, Y.; Haileb, M.; Habtegebrielb, K. Effect of zinc and phosphorus fertilizers application on yield and yield components of faba bean (Vicia faba L.) grown in calcaric cambisol of semi-arid northern Ethiopia. J. Soil Sci. Environ. Manag. 2012, 3, 320-326.

23. Naresh, R.K.; Kumar, M.; Singh, S.P.; Dwivedi, A.; Kumar, R. Enhancing nutrient use efficiency through next generation fertilizers in vegetable and field crops. In Agricultural-Based Interventions for Sustainable Food Security and Climate Change New Delhi, India; En Kumar, M., Kumar-Singh, R., Singh, R., Kumar-Verna, R., Kumar, H., Kumar-Rajput, R., Eds.; AkiNik: Delhi, India, 2018; pp. 91-97.

24. Kyrkby, E.; Römheld, V. Micronutrientes en la fisiología de las plantas: Funciones, absorción y movilidad. Informaciones Agronómicas 2008, 68, 1-3.

25. Kosesakal, T.; Unal, M. Role of zinc deficiency in photosynthetic pigments and peroxidase activity of tomato seedlings. IUFS J. Biol. 2009, 68, 113-120.

26. Brown, P.H.; Cakmak, I.; Zhang, Q. Form and Functions of Zinc in Plants; Kluwer Academic Publishers: Dordrecht, The Netherlands, 1995; pp. 9-106.

27. Mankad, M.; Fougat, R.S.; Patel, A.; Mankad, P.; Patil, G.; Subhash, N. Physiological and Biochemical Effects of Zinc Oxide Nanoparticles on Rice (Oryza sativa L.). Adv. Biores. 2017, 8, 208-217.

28. Sánchez, E.; Ruiz, J.M.; Romero, L. Compuestos nitrogenados indicadores de estrés en respuesta a las dosis tóxicas y deficientes de Nitrógeno en frijol ejotero. Nova Sci. 2016, 8, 228-244. [CrossRef]

29. Sida-Arreola, J.P.; Sánchez, E.; Preciado-Rangel, P.; Márquez-Quiroz, C. Does zinc biofortification affects the antioxidant activity in common bean? Cogent Food Agric. 2017, 3, 1283725. [CrossRef]

30. Siddiqui, M.H.; Al-Whaibi, M.H.; Firoz, M.; Al-Khaishany, M.Y. Role of nanoparticles in plants. In Nanotechnology and Plant Sciences; Siddiqui, M.H., Al-Whaibi, M.H., Mohamed, F., Eds.; Springer: New York, NY, USA, 2015; pp. 19-35.

31. Meloni, D.A.; Silva, D.M.; Ledesma, R.; Bolzón, G.I. Mineral nutrition and photosynthesis of Prosopis alba (Fabaceae) seedlings under saline stress. Cuadernos de Investigación UNED 2017, 9, 297-304.

32. Maldonado, J.M. Asimulación del nitrógeno y del azufre. Azcón-Bieto. In Fundamentos de Fisiología Vegetal; Talón, M., Ed.; McGraw-Hill Interamericana: Madrid, España, 2013; pp. 287-304.

33. El-Habbasha, S.F.; Abd El-Salam, M.S. Response of two canola varieties (Brassica napus L.) to nitrogen fertilizer levels and zinc foliar application. Int. J. Acad. Res. 2010, 2, 60-66.

34. Aslam, W.; Arfan, M.; Shahid, S.A.; Anwar, F.; Mahmood, Z.; Rashid, U. Effects of exogenously applied Zn on the growth, yield, chlorophyll. Int. J. Chem. Biochem. Sci. (IJCBS) 2014, 5, 11-15.

35. Du, W.; Tan, W.; Peralta-Videa, J.R.; Gardea-Torresdey, J.L.; Ji, R.; Yin, Y.; Guo, H. Interaction of metal oxide nanoparticles with higher terrestrial plants: Physiological and biochemical aspects. Plant Physiol. Biochem. 2017, 110, 210-225. [CrossRef] [PubMed]

36. Samreen, T.; Shah, H.U.; Ullah, S.; Javid, M. Zinc effect on growth rate, chlorophyll, protein and mineral contents of hydroponically grown mungbeans plant (Vigna radiata). Arab. J. Chem. 2017, 10, S1802-S1807. [CrossRef] 
37. Broadley, M.; Brown, P.; Cakmak, I.; Rengel, Z.; Zhao, F. Function of nutrients: Micronutrients. In Mineral Nutrition of Higher Plants; Marschner, P., Ed.; Academic Press: Inglaterra, UK, 2012; pp. 191-243.

38. Núñez, R. El suelo como medio natural en la nutrición de los cultivos. In Nutrición de Cultivos; Alcántar, G., Trejo-Téllez, L.I., Eds.; Colegio de Postgraduados: México, 2013; pp. 93-149.

39. Wang, C.; Zhang, S.H.; Wang, P.F.; Hou, J.; Zhang, W.J.; Li, W.; Lin, Z.P. The effects of excess Zn on mineral nutrition and antioxidative response in rapeseed seedlings. Chenosphere 2009, 75, 1468-1476. [CrossRef] [PubMed]

(C) 2019 by the authors. Licensee MDPI, Basel, Switzerland. This article is an open access article distributed under the terms and conditions of the Creative Commons Attribution (CC BY) license (http:/ / creativecommons.org/licenses/by/4.0/). 